\title{
Fatty acids and sterols evolution during the ripening of olives from the Moroccan Picholine cultivar
}

\author{
By H. Ajana ${ }^{a}$, A. El Antari ${ }^{\text {b* }}$ and A. Hafidi ${ }^{\mathrm{a}}$ \\ a: Laboratoire Associé francophone Sciences des Aliments, Departement de Biologie, Faculté des Scien- \\ ces Semlalia Marrakech B.P. S/15. \\ b: Laboratoire de la technologie des huiles, Programme-Olivier, Institut National de la Recherche Agrono- \\ mique Marrakech B.P. 533.
}

\section{RESUMEN}

Evolución de los ácidos grasos y de los esteroles durante la maduración de aceitunas de la variedad Picholine Marroquí.

De junio a febrero se recogieron 13 muestras de aceitunas de olivos de la variedad Picholine Marroquí. Los aceites de las primeras muestras tuvieron altos niveles de acidez $(>1 \%)$ que posteriormente disminuyeron rápidamente para luego estabilizarse entre 0.36 y $0.44 \%$. La evolución de los ácidos grasos totales mostró unos niveles relativamente altos de C18:3 en las primeras muestras. Estas proporciones disminuyeron durante el proceso de maduración y se estabilizaron a 0.8 - 0.9\% a comienzos de noviembre. El C16:0 disminuyó mientras que el C18:2 aumentó durante el proceso de maduración. Los ácidos grasos monoinsaturados predominaron en la posición Sn 2 glicerol. La suma de las proporciones de los ácidos palmítico y esteárico en esta posición llegó a ser más baja del 1.5\% entre mediados de noviembre y principio de enero.

La composición química de los ácidos grasos del mesocarpo es cuantitativamente y cualitativamente similar a la observada para los ácidos grasos totales de la aceituna en su totalidad. Sin embargo, los ácidos grasos totales de las semillas son cuantitativamente diferentes de los del mesocarpo. Las proporciones de estos ácidos grasos permanecieron estables desde mediados de septiembre. El $\beta$-sitosterol es el principal esterol en todas las muestras con una proporción que excedía el $84 \%$. El $\Delta 5$ avenasterol alcanzó un máximo en la segunda mitad de enero al mismo tiempo que el $\beta$-sitosterol tuvo sus niveles más bajo. Los niveles de campesterol variaron entre 3 y $3.5 \%$ y los niveles de estigmasterol se estabilizaron alrededor del $1 \%$ hasta el comienzo de noviembre para luego disminuir al $0.5 \%$.

PALABRAS-CLAVE: Aceituna - Acido graso - Esterol Maduración - Variedad Picholine Marroquí.

\section{SUMMARY}

Fatty acids and sterols evolution during the ripening of olives from the Moroccan Picholine cultivar.

From june to february 13 olive samples from Moroccan Picholine olive trees were collected. The oils from the first samples have high acidity levels $(>1 \%)$. But this latter decreases rapidly then stabilizes between 0.36 and $0.44 \%$. The evolution of the total fatty acids shows a relatively high rates of C18:3 in the first samples. These proportions decrease during the ripeness process and stabilize at $0.8-0.9 \%$ from begining november. The C16:0 decreases while $C 18: 2$ increases during the ripening. Monoinsaturated fatty acid predominate in the Sn 2 glycerol position. The sum of the palmitic and the stearic acids proportions in this position become less than $1.5 \%$ between mid november and begining january.

The chemical composition of the mesocarp fatty acids is quantitatively and qualitatively similar to that observed for the total fatty acids of the whole olives. However, the total fatty acids of the olive seed are quantitatively different from those of the mesocarp. The proportions of these fatty acids remain stable since mid september. The $\beta$ sitosterol is the main sterol in all our samples with a proportion exceeding $84 \%$. The $\Delta 5$ avenasterol reaches a maximum at january 2 nd at this time the $\beta$ sitosterol have its lowest rate. The campesterol rates vary between 3 and $3.5 \%$ and the rates of the stigmasterol stabilize around $1 \%$ until the begining november then it decreases to $0.5 \%$.

KEY-WORDS: Fatty acid - Moroccan Picholine variety - Olive - Ripening - Sterol.

\section{INTRODUCTION}

Oleiculture in Morocco is mainly represented by only one variety: the moroccan Picholine (Loussert, 1989). Thus, we found it in different regions of Morocco under different climate conditions. Fatty acids and sterols of olive oils from the european varieties are well studied and many studies had shown that the chemical composition of the oil changes during the ripeness of the olives. Thus, the palmitic, the stearic and the linolenic acids proportions decrease during the ripeness of olives from the Carolea and Frantoï varieties, while the oleic acid increases (Fiorino et al. 1991). Concerning the Picual, Hojiblanca and Zorzalena varieties, a decrease of palmitic and oleic acids, and an increase of linolenic acid is observed (Duran, 1990). According to Marzouk, the rates of the linoleic and palmitoleic acids does not undergo any variations during the ripeness of the Chemlali-olives (Marzouk et al., 1981). Also, this variety shows very high rates of the stearic acid (21\%) in the early stages of the fruit development, these rates decrease at ripeness and stabilize around $2 \%$. The proportions of this later are reported to be dependent of the cultivar (Fiorino et al., 1991). Generaly, the oleic acid represents an average of $73 \%$ in the north Africa olive oils 
(Feinberg et al., 1987), but very important variations can be encountred. In Algeria, olive oils can contain up to $80 \%$ of the oleic acid (Talantikite et al., 1988), in Lybia this rate doesn't exceed $45 \%$ (Kiritsakis et al., 1987).

The sterolic composition can also vary during the ripeness process. Different sterolic compositions are reported for the moroccan Picholine. Thus, the $\Delta 5$ Avenasterol and $\beta$ Sitosterol represent respectively $0.4 \%$ and $93.6 \%$ (Zerrouk, 1984). Other authors have reported different proportions respectively $7.3 \%$ and $88.3 \%$ for these sterols (Castang et al., 1976). These variations can be caused by differences in the levels of ripeness of the olives.

In this work we followed the chemical composition of olives and their oil from the early stages of fruit development until their ripeness.

\section{MATERIAL AND METHODS}

Olive sampling: It is carried out in the Marrakech region. Oleiculture represents in this region $24 \%$ at the national level (M.A.M.V.A., 1996). Adult olive trees are used for sampling. Those are planted in a low density (55 trees/ha). The sampling period beggins from June and lasts until February. Samples are analysed as follows:

Lipids extraction is fullfiled according to a modified Folch method (Marzouk et al., 1981): The moulded olives are macerated under agitation for 10 min in a conditionned room $\left(T^{\circ}=4^{\circ} \mathrm{C}\right)$ successively in three solvent mixtures:

Extraction no 1: Chloroforme-Methanol (2/1);

Extraction no 2: Hexane - Methanol (2/1);

Extraction no 3: Chloroforme - Methanol (2/1).

The three extracts are mixed together to form one phase and are washed with water. The organic phase which contains the lipids is recuperated after centrifugation.

Free fatty acids (FFA) are determined according to AFNOR method (NF. T. 60-204) (A.F.NOR., 1984).

Total fatty acids: Methyl esters are prepared according the AFNOR method (NF.T. 60-233) (A.F.NOR., 1984). Gas liquid chromatography (GLC) analysis is carried out in a Girdel 3000 Chromatograph, equiped with a FID detector and a spectra - physics 4 100 calculator. A carbowax $20 \mathrm{M}$ column is used $(L=25$ $\mathrm{m} ; \phi=0,21 \mathrm{~mm})$. The identification is accomplished with standard injection.

Sn 2 Glycerol fatty acids: A IUPAC method (II-D. 27-2.210) (IUPAC, 1979) is used for this determination. 2-mono-glycerides are isolated according to Muderhwa procedure (Muderhwa et al., 1987). The mobile phase used for the Thin layer chromatography (TLC) is:

Hexane / diethyl ether / acetic acid (10/90/1).
Sterols analysis: Insaponifiable matter is isolated and separated on TLC according to NF.T. 60 - 205 and NF.T. 60 - 232 methods (A.F.NOR., 1984). A GLC separation is carried out using a fused silicagel column $(L=25 ; \phi=0,5 \mathrm{~mm})$ with a $Q C 3$ (BP5 SGE) stationary phase. Identification is allowed by standard injection.

\section{RESULTS AND DISCUSSION}

\section{Free fatty acids content evolution}

Free fatty acids (FFA) content evolution shows high values ( $1 \%$ ) in the first month of our sampling. This rate decreases rapidly and remains all the time bellow $1 \%$ since mid august. High acidity levels are obtained also for some other oils from seeds at early stages of development (Privett et al., 1973).

Table I

Free fatty acids content evolution

\begin{tabular}{cc}
\hline Dates of sampling & Free fatty acids $(\%)$ \\
\hline $6 / 6$ & 3.60 \\
$13 / 7$ & 1.05 \\
$15 / 8$ & 0.90 \\
$16 / 9$ & 0.77 \\
$5 / 10$ & 0.69 \\
$16 / 10$ & 0.36 \\
$1 / 11$ & 0.37 \\
$16 / 11$ & 0.44 \\
$3 / 12$ & 0.39 \\
$17 / 12$ & 0.37 \\
$2 / 1$ & 0.29 \\
$16 / 1$ & 0.36 \\
$2 / 2$ & 0.36 \\
\hline
\end{tabular}

From october the 16 th until february the $2 \mathrm{nd}$, the acidity levels remain almost similar (0.36 - $044 \%)$. In fact, the acidity rarely exceeded $0.5 \%$ if olives are extracted immediatly after harvest (Wild, 1988). A comparable evolution (between September and February) is reported for Twelve italian varieties (Camera et al., 1975).

In the first month, the triacylglycerols biosynthesis remain low. In this stage the biosynthesis of partial 
glycerides, free fatty acids and phospholipids predominates over the synthesis of triacylglycerols. Thin layer chromatography shows no triacylglycerols in the 6th June sample. The measured acidity in this stage could correspond both to FFA and to the phosphatidic acid. These components are the subtrates for the triacylglycerols biosynthesis.

Considering their acidity, the olive oils are subdivided to different quality classes (Loussert et al., 1978; C.O.I., 1991 and Wessels, 1992). Our results show that the moroccan Picholine contains (from december to January) high levels of an oil which can be classified as extra virgin.

The high acidity level frequently found in the commercial Moroccan olive oil is probably caused with inadequate practices (harvest, storage and transport).

\section{Fatty acids composition}

\section{a Total fatty acids}

Compared to other vegetable oils, olive oil is characterized with a domination of monoinsaturated fatty acids. These latters represent $71 \%$ in the major of our samples. The two other classes represent $10 \%$ to $18.6 \%$.

Concerning the total fatty acids (Table II), different evolutions are observed depending on the nature of the fatty acids. Rates of minor fatty acids $\mathrm{C20}: 0$ and C20:1 remain almost invariable and vary only between 0.3 to $0.5 \%$ during all the sampling period. Palmitic C16:0, palmitoleic C16:1 and linolenic C18:3 acids decrease during olive ripeness (samples 2 to 7 ). Their rates become stable in the two last samples. The palmitic acid registred an important decrease from $16.3 \%$ in the first sample to $7.4 \%$ at february the 2nd. During the first months of fruit development, the oil has relatively high content of $\mathrm{C} 18: 3(4.5 \%)$. This rate decreases and at the beggining of november it stabilizes at $0.9-0.8 \%$. C18:0 and C18:2 show a slight and progressive increase. C18:1 rate increases from $65 \%$ and reaches $72 \%$ at mid august, then stabilizes beyond this value until mid december. After this date, it increases and reaches $75.6 \%$ in the last sample.

The evolution of the different fatty acids of the moroccan Picholine is similar to that of some italian varieties like Dritta, Coratina, Nebbio, Cucco... (Camera et al., 1975). The similarity is mainly remarquable for the palmitic, the oleic and the linolenic acids. Concerning the stearic and the linolenic acids a rather stable evolution is observed in italian varieties (Camera et al., 1975 and Fiorino et al., 1991). Fiorino noted a decrease of the palmitic and linolenic acids and a slight increase of the oleic acid for the Carolea and Frantoïo varieties. Concerning the moroccan Picholine, an increase of the linolenic acid during the ripeness of olives had been reported (Belaiche, 1983). This is completly different from what we have found. Olive oil from the moroccan Picholine shows at ripeness, an evolution and a total tatty acids composition quantitatively different from that reported for a tunisian variety (Chemlali). In the oil from this variety, the stearic acid proportions decrease during the ripeness process from $21.5 \%$ in young olives and stabilizes in ripe olives around $2 \%$ (Marzouk et al., 1981). For the moroccan Picholine, a slight increase (from 1.9 to $3.2 \%$ ) is observed. Fiorino reported that the evolution of the stearic acid is significantly different from one cultivar to another (Fiorino et al., 1991). For the linolenic and the stearic acids, any significant variations in their rates had not been observed for the Chemlali variety (Marzouk et al., 1981). For the moroccan Picholine these two fatty acids decrease slightly.

Table II

Total fatty acids evolution

\begin{tabular}{rrrrrrrrr}
\hline $\begin{array}{r}\text { Dates of } \\
\text { sampling }\end{array}$ & & \multicolumn{7}{c}{ Fatty acids } \\
& C16:0 & C16:1 & C18:0 & C18:1 & C18:2 & C18:3 & C20:0 & C20:1 \\
\hline $13 / 7$ & 16.3 & 0.9 & 1.9 & 65.4 & 10.2 & 4.5 & 0.4 & 0.3 \\
$15 / 8$ & 13.5 & 0.8 & 2.2 & 72.2 & 8.2 & 2.1 & 0.6 & 0.5 \\
$16 / 9$ & 14.1 & 0.8 & 2.2 & 72.2 & 8.6 & 1.3 & 0.4 & 0.4 \\
$5 / 10$ & 13.4 & 0.8 & 2.3 & 72.1 & 9.5 & 1.0 & 0.4 & 0.4 \\
$16 / 10$ & 12.5 & 0.7 & 2.2 & 72.3 & 10.4 & 1.2 & 0.4 & 0.4 \\
$1 / 11$ & 10.5 & 0.5 & 2.4 & 72.8 & 12.2 & 0.9 & 0.4 & 0.5 \\
$16 / 11$ & 10.4 & 0.5 & 2.5 & 71.0 & 14.0 & 0.9 & 0.3 & 0.4 \\
$3 / 12$ & 9.4 & 0.5 & 2.5 & 72.0 & 13.8 & 0.9 & 0.4 & 0.5 \\
$17 / 12$ & 9.1 & 0.4 & 2.8 & 73.0 & 13.2 & 0.8 & 0.4 & 0.5 \\
$2 / 1$ & 7.3 & 0.3 & 3.5 & 73.6 & 13.5 & 0.8 & 0.4 & 0.5 \\
$16 / 1$ & 8.1 & 0.4 & 3.0 & 74.3 & 12.4 & 0.9 & 0.4 & 0.5 \\
$2 / 2$ & 7.4 & 0.4 & 3.2 & 75.6 & 12.0 & 0.8 & 0.3 & 0.4 \\
\hline
\end{tabular}

In spite of the big morphological ressemblance between the moroccan Picholine and the algerian Sigoise, their oils show quantitatively different chemical compositions (Talantikite et al., 1988).

Regional climate conditions and agricultural technics would also influence the chemical composition. But, the cultivar factor remains the most important. The insaturated fatty acids fraction would be the more dependent on the cultivar (Cimato, 1990).

Works of Pannelli on the late varieties or oil producing varieties show that the accumulation of oleic and linoleic acids is different from a variety to another (Pannelli et al., 1990). 


\section{b Sn2 Glycerol fatty acids}

The chemical composition of the Sn2 glycerol fatty acids shows a clear affinity of the insaturated fatty acids for this position in all our samples. The monoinsaturates are represented mainly by the oleic acid which represent at least $76 \%$ (october 16th) of the total fatty acids in this position. In the major of our samples this rate exceeds $80 \%$ (Tables III \& IV). Polyinsaturated fatty acids are also very represented in this position. Their proportions vary between $10.4 \%$ (november 1st) and $17.7 \%$ (january 16th). These latters are mainly represented by linoleic acid whose rate varies between 8 to $14 \%$ (Table IV) in the total fatty acids.

Table III

Evolution of the Sn2 glycerol fatty acids classes

\begin{tabular}{cccc}
\hline Dates of sampling & Saturated & Monoinsaturated & Polyinsaturated \\
\hline $16 / 9$ & 2.60 & 84.44 & 12.95 \\
$5 / 10$ & 7.20 & 79.20 & 13.57 \\
$16 / 10$ & 7.15 & 77.19 & 15.65 \\
$1 / 11$ & 3.07 & 86.54 & 10.38 \\
$16 / 11$ & 1.26 & 82.71 & 16.02 \\
$3 / 12$ & 0.86 & 82.70 & 16.43 \\
$17 / 12$ & 1.17 & 81.12 & 17.65 \\
$2 / 1$ & 1.55 & 83.54 & 14.90 \\
$16 / 1$ & 2.13 & 80.16 & 17.69 \\
$2 / 2$ & 1.78 & 84.26 & 13.96 \\
\hline
\end{tabular}

Table IV

Sn2 glycerol fatty acids evolution

\begin{tabular}{rllllll}
\hline $\begin{array}{r}\text { Dates of } \\
\text { sampling }\end{array}$ & C16:0 & C16:1 & C18:0 & C18:1 & C18:2 & C18:3 \\
\hline $16 / 9$ & 2.39 & 1.05 & 0.21 & 83.39 & 11.87 & 1.08 \\
$5 / 10$ & 5.39 & 0.96 & 1.81 & 78.24 & 11.87 & 1.5 \\
$16 / 10$ & 6.19 & 0.91 & 0.96 & 76.28 & 14.99 & 0.66 \\
$1 / 11$ & 2.42 & 0.59 & 0.65 & 85.95 & 9.89 & 0.49 \\
$16 / 11$ & 1.15 & 0.74 & 0.11 & 81.97 & 14.72 & 1.3 \\
$3 / 12$ & 0.75 & 0.48 & 0.11 & 82.22 & 15.84 & 0.59 \\
$17 / 12$ & 1.01 & 0.38 & 0.16 & 80.74 & 15.92 & 1.73 \\
$2 / 1$ & 1.3 & 0.21 & 0.25 & 83.33 & 14.37 & 0.53 \\
$16 / 1$ & 1.45 & 0.47 & 0.68 & 79.69 & 17.29 & 0.4 \\
$2 / 2$ & 1.47 & 0.33 & 0.31 & 83.93 & 13.53 & 0.43 \\
\hline
\end{tabular}

From november 16 th, the total of palmitic and stearic acids doesn't exceed $2 \%$. The same result is reported by Zerrouk. However, slight different results are obtained by this researcher concerning $\mathrm{C} 18: 1$ and C18:2 (Zerrouk, 1984).
According to the International Oleicol Council reglamentation of virgin olive oil, the total proportion of palmitic and stearic acids must not exceed $1.5 \%$. Only oils obtained from november 16th to january 2nd apply to this rule.

\section{c The total fatty acids of the mesocarp}

At ripeness, the mesocarp can represent up to $85 \%$ of the total weight of the olives (Kiritsakis et al., 1987). The global evolution of the different fatty acids of the mesocarp is similar to that observed for the fatty acids from the whole olives (Table V).

Table V

The mesocarp total fatty acids evolution

\begin{tabular}{rcccccccc}
\hline $\begin{array}{r}\text { Dates of } \\
\text { sampling }\end{array}$ & & & \multicolumn{7}{c}{ Fatty acids (\%) } \\
& C16:0 & C16:1 & C18:0 & C18:1 & C18:2 & C18:3 & C20:0 & C20:1 \\
\hline $13 / 7$ & 16.7 & 0.7 & 2.2 & 68.7 & 7.8 & 2.9 & 0.4 & 0.5 \\
$15 / 8$ & - & - & - & - & - & - & - & - \\
$16 / 9$ & 15.6 & 1.3 & 1.8 & 71.4 & 8.0 & 1.3 & 0.3 & 0.2 \\
$5 / 10$ & 15.2 & 0.8 & 1.8 & 70.4 & 9.8 & 1.2 & 0.3 & 0.3 \\
$16 / 10$ & 13.8 & 0.6 & 1.8 & 70.6 & 11.6 & 1.0 & 0.3 & 0.3 \\
$1 / 11$ & 12.6 & 0.5 & 2.0 & 71.3 & 11.5 & 0.9 & 0.4 & 0.6 \\
$16 / 11$ & 10.7 & 0.4 & 2.6 & 70.9 & 13.9 & 0.8 & 0.3 & 0.3 \\
$3 / 12$ & 10.6 & 0.4 & 2.3 & 73.1 & 11.9 & 0.8 & 0.4 & 0.4 \\
$17 / 12$ & 9.7 & 0.4 & 2.6 & 71.7 & 13.9 & 0.9 & 0.4 & 0.4 \\
$2 / 1$ & 8.7 & 0.3 & 3.2 & 76.1 & 10.1 & 0.7 & 0.4 & 0.4 \\
$16 / 1$ & 8.8 & 0.3 & 3.0 & 75.0 & 11.5 & 0.7 & 0.3 & 0.4 \\
$2 / 2$ & 7.4 & 0.4 & 3.2 & 75.6 & 12.0 & 0.8 & 0.3 & 0.4 \\
\hline
\end{tabular}

Since the early stages of the olive development, the oleic acid show high levels (70 - 73\%). Its evolution is characterized by a relative stability, higher proportions $(75-76 \%)$ are obtained in the last samples. The palmitic and linoleic present opposite evolutions, the palmitic decreases while the linoleic increases. Palmitoleic and linolenic acid decrease until november, then they show stable proportions during the remaining samples. All other fatty acids don't show any noticeable variation during the fruit development. These proportions are almost similar to that obtained for the total fatty acids of the whole olives.

\section{d Total fatty acids of olive seeds'oil}

The fatty acids of the olive seeds'oil are all qualitatively identic to those of the mesocarp, but the C16:1 which proportions are negligible. Results in table VI show that all the fatty acids proportions remain invariable in all the studied period. Only the oleic and linoleic acids have different proportions in 
the first samples. The chemical composition of fatty acids reaches a stability since mid september. In fact, at this date the olive kernel had completed its development.

Table VI

Olive seeds'oil total fatty acids

\begin{tabular}{rccccccc}
\hline $\begin{array}{c}\text { Dates of } \\
\text { sampling }\end{array}$ & C16:0 & C18:0 & C18:1 & C18:2 & C18:3 & C20:0 & C20:1 \\
\hline $13 / 7$ & 7.8 & 2.5 & 59.4 & 28.9 & 0.4 & 0.4 & 0.5 \\
$16 / 9$ & 7.0 & 2.6 & 66.4 & 22.3 & 0.3 & 0.6 & 0.7 \\
$5 / 10$ & 8.1 & 2.6 & 67.1 & 21.4 & 0.2 & 0.3 & 0.4 \\
$16 / 10$ & 7.1 & 2.7 & 67.4 & 21.2 & 0.3 & 0.5 & 0.8 \\
$1 / 11$ & 6.9 & 2.9 & 67.3 & 21.1 & 0.3 & 0.6 & 0.9 \\
$16 / 11$ & 6.9 & 2.8 & 68.1 & 20.4 & 0.3 & 0.6 & 0.8 \\
$3 / 12$ & 6.7 & 3.0 & 67.1 & 21.4 & 0.3 & 0.6 & 0.9 \\
$17 / 12$ & 7.0 & 2.9 & 67.0 & 21.5 & 0.2 & 0.5 & 0.8 \\
$2 / 1$ & 6.9 & 3.0 & 67.1 & 20.9 & 0.3 & 0.6 & 1.0 \\
$16 / 1$ & 7.2 & 3.0 & 67.2 & 20.8 & 0.3 & 0.5 & 0.8 \\
\hline
\end{tabular}

A comparison of the proportions of fatty acids of the olive seeds and those of mesocarp show that the mesocarp is richer in oleic, palmitic and linoleic acids than the olive seeds. But, the olive seed contains higher rates of linoleic acid $(21 \%)$. This fatty acid composition in the olive seeds remembers us that the other common oleaginous seeds (Feinberg et al., 1987 and Alter et al., 1982).

\section{Evolution of the unsaponifiable matter content.}

The evolution of the unsaponifiable matter content presented two phases: The first is situated between August 15 th and octobre 16 th with a decreasing proportions. The second which beggins from november 1 st is characterized by a relative stability (around $1 \mathrm{mg} / 100 \mathrm{~g}$ of oil) of these unsaponifiable matter content rates (Table VII).

\section{The evolution of the sterolic composition.}

Every vegetable oil have a specific sterol composition. Thus, they have a great importance in adulteration detection (Feinberg et al., 1987; Gordan et al., 1989 and Johansson et al., 1979). This chemical components are also used for varietal characterisations (Castang et al., 1976 and Kiosseglou et al., 1989), and are reported to be indicators of the best period of harvest (Fiorino et al., 1991).

Results in table VII show that the $\beta$ sitosterol is the major component during all the period of sampling, with rates exceeding in all cases $84 \%$.
Proportions of $\beta$ sitosterol and $\Delta 5$ avenasterol show opposite evolutions. The $\beta$ sitosterol rates decrease and reach a minimum in the sample of january 2 nd. In another way, the $\Delta 5$ avenasterol increases and reaches a maximal rate at the same date (january 2nd). This evolution show a ressemblance with that reported for some italian varieties (Camera et al., 1975). But, the date at the $\beta$ sitosterol rate is maximal and the $\Delta 5$ avenasterol rate is the lowest, is not the same for the moroccan Picholine (january 2nd) and the italian varieties (december 12th). This difference may be attributed to a varietal or/and climate conditions.

Table VII

\section{Unsaponifiable matter content and sterols evolution}

\begin{tabular}{rccccc}
\hline $\begin{array}{c}\text { Dates of } \\
\text { sampling }\end{array}$ & $\begin{array}{c}\text { Unsaponifiable } \\
\text { matter }\end{array}$ & Campesterol & Stigmasterol & $\beta$ Sitosterol & $\Delta^{5}$ Avenasterol \\
\hline $15 / 8$ & 2.4 & 4.99 & 1.07 & 92.26 & 1.66 \\
$16 / 9$ & 1.7 & 2.97 & 0.91 & 93.38 & 2.74 \\
$5 / 10$ & 1.6 & 2.93 & 0.85 & 93.19 & 3.03 \\
$16 / 10$ & 0.5 & 2.88 & 0.85 & 92.89 & 3.36 \\
$1 / 11$ & 0.9 & 3.47 & 1.03 & 88.30 & 7.20 \\
$16 / 11$ & 0.8 & 2.88 & 0.66 & 89.04 & 7.41 \\
$3 / 12$ & 0.8 & 2.59 & 0.52 & 89.51 & 7.37 \\
$17 / 12$ & 1.1 & 2.85 & 0.64 & 87.53 & 8.97 \\
$2 / 1$ & 0.6 & 3.58 & 0.56 & 84.96 & 10.88 \\
$16 / 1$ & 1.1 & 3.21 & 0.74 & 88.32 & 7.72 \\
$2 / 2$ & 1.0 & 3.41 & 0.89 & 86.50 & 9.2 \\
\hline
\end{tabular}

At the exception of the sample of $15 / 8$ in which it represents $5 \%$ of the total sterols, the campesterol shows low proportions shifting between 3.0 and $3.5 \%$ during the period of our sampling. Stigmasterol rates stabilize around $1 \%$ until mid november from which these rates decrease and vary between 0.5 and $0.66 \%$. A slight increase of these rates is observed in the two last samples. This evolution of these two sterols is different of that reported by Camera. This latter had observed, for some italian varieties, a decrease of the campesterol rates and an increase for the stigmasterol proportions during the ripeness process. If we can easily find the sterolic composition of the moroccan olive oil, we haven't found any work about the evolution of this fraction during the ripeness of olives. Thus, the sterolic composition reported by Castang corresponds to that we have found at novembre 1st and could almost be considered similar to that obtained until the last of our sampling period. However, the results reported by Zerrouk seem to be the same of those we have obtained in the early stages of the ripeness process. 


\section{CONCLUSION}

The analysis of the evolution of the oil content, the free fatty acids and chemical composition of the oil shows that the period between december the 3rd and january the 2nd, is the most appropriate for harvesting the olives from the moroccan Picholine in the Marrakech region. In this period, the olives contain an extra virgin oil with a stable chemical composition. Total fatty acids analysis had shown that the composition of the olive seeds oil is different from that of the mesocarp and is rather similar to that of other seed oils like soybean oil.

\section{ACKNOWLEDGEMENTS}

The authors express their sincere gratitude to the IFS (grant № E 1480-1) and the AUPELF (LAF 313) organisations for supporting this research project. We gratfully acknowledge the $\operatorname{Pr}$ A. CERT, Head of the Analysis Department of the Instituto de la Grasa - Sevilla (Spain) for his helpful advice.

\section{REFERENCES}

A.F.NOR, (1984).- «Recueil de normes françaises des corps gras, graines oleagineuses et produits derives".- $3^{\text {eme }}$ Ed.- AFNOR., Paris.

Alter, M. and Gutfinger, T. (1982)._- "Phospholipids in several vegetable oils".-La Rivista Italiana Delle Sostanze Grasse. 59, 14-18.

Belaiche T. (1983)._- Evolution de la composition de trois variétés d'olives en certains constituants au cours de la maturation".-Mémoire d'assistanat, département de technologie alimentaire, E.N.A, Meknes, Maroc,

Camera, L., Angerosa, F. y Cucurachi, A. (1975)."L'evoluzione della fraczione sterolica dell'olio con il procedere della maturazione delle olive".-Estratto Dagli Annali Dell'Instituto Sperimentale per la Elaiotecnia Pescara. 5, 3-36.

Castang, J., Olle, M., Derbesy, M. et Estienne, J. (1976)."Composition de la fraction stérolique de quelques huiles alimentaires (1)".-Extrait des annales des falsifications. 737, 1-29.

Cimato A. (1990).- «La qualité de l'huile d'olive et les facteurs agronomiques".-Olivae. 31, 20-31.

C.O.I. (1991).— «Norme commerciale internationale applicable aux huiles d'olive et aux huiles de grignons d'olive".-COI/T.15/NC n. 1/Rév. 2, 3-4.

Duran, M. (1990)._- Relationship between the composition and ripening of the olive and quality of the oil».-Acta Horticulturae. 286, 441-451.
Feinberg, M., Favier, C. et Ripert, J. (1987)-— «Répertoire Général des Aliments, Tome 1, Technique et Documentation.-Ed Lavoisier., Paris.

Fiorino, P. et Nizzigrifi, F. (1991). - «Maturation des olives et variations de certains composants de l'huile".Olivae. 35, 25-33.

Gordan, H. and Griffith, E. (1989).— «Analysis of steryl esters".-Actes du congré international "Chevreul» pour l'étude des corps gras, Angers 6-9 juin 1989, Tome 1.185-192.-Ed.- ETIG., Paris.

IUPAC, (1979).— - Determination de la teneur en acide gras en position 2 dans les triglycerides: method II.D.27.2.210".-5th Ed., 1-6.

Johansson, A. and Hoffmann, I. (1979).- «The effect of processing on the content and composition of free sterols and sterol esters in soybean oil».-J. Am. Oil Chem. Soc. 56, 886-889.

Kiosseglou, and Boskons, D. (1989).- - The composition of free and esterified sterols in tomato seed oils".-Oléagineux. 44, 111-113.

Kiritsakis, A. and Markakis, P. (1987).- «Olive oil: a review».-Advance in food research. 31, 453-482.

Loussert, R. et Brousse, G. (1978)._- «'olivier, Techniques agricoles et productions mediterranéennes».-Ed.- G. P. Maisonneuve et Larose., Paris.

Loussert, R. (1989)._- «'oléiculture marocaine, situation actuelle et perspectives d'avenir».-Olivae. 25, 8-12.

M.A.M.V.A, (1996).- -L'oléiculture marocaine».-Le Pole Alimentaire. 3, 14-17.

Marzouk, B. et Cherif, A. (1981).- «Lipogénese dans l'olive I. Formation des lipides neutres".-Oléagineux. $36,77-82$.

Mazliak, P. (1968)._- «e métabolisme des lipides dans les plantess supérieures".-Ed. Masson and Cie, Paris.

Muderhwa, J., Dhuique, C., Pina, M., Galzy, P., Grignac, P. et Graille, J. (1987).- — «épartition interne/externe des acides gras des triglycérides de quelques huiles gamma linoléniques".-Oleagineux. 42, 207-211.

Pannelli, G., Famiani, F., Servili, M. and Montedoro, F. (1990).- «Agro-climatic factors and characteristics of the composition of virgin olive oils".-Acta Horticulturae. 286, 477-480.

Privett, S., Dougherty, A., Erdahl, L. and Stolyhwo, A. (1973). - «Studies on lipid composition of developing soybeans".-J. Am. Oil Chem. Soc. 50, 516-520.

Talantikite, M. et Ait amar, H. (1988).- "Composition acidique des huiles d'olives des trois cultivars d'algérie".-Olivae. 23, 29-31.

Wessels H. (1992). - "Olivenölkategorien und inre merkmale-regelungen der Europäischen Gemeinsehaft».—Fat Sci: Technol. 94, 130-137.

Wild, M. (1988)._- Incidence de la qualité sur la commercialisation".-L'économie de l'olivier, séminaire CEE-CIHEAM, Tunisie, 20-22 Janvier 1987.-Ed. -Allaya (m)-CEE (dgi)/ciheam, 219.

Zerrouk, K. F. (1984). - «Etude de corps gras d'origine marocaine».-These de docteur ingénieur, université de provence, Marseille. 